\title{
INTERPRETIVE STRUCTURAL MODELING IN EARNED VALUE MANAGEMENT
}

\author{
Morteza BAGHERPOUR (D) 1 , Mohammad KHAJE ZADEH ${ }^{1}$, \\ Amin MAHMOUDI ${ }^{2 *}$, Xiaopeng DENG ${ }^{2}$ \\ ${ }^{1}$ Department of Industrial Engineering, Iran University of Science and Technology, Tehran, Iran \\ ${ }^{2}$ Department of Construction and Real Estate, School of Civil Engineering, Southeast University, \\ 210096 Nanjing, China
}

Received 20 June 2019; accepted 21 October 2019

\begin{abstract}
The primary purpose of the current study is introducing a comprehensive approach to identify the relationship among different criteria in Earned Value Management (EVM). EVM is a well-known approach in project management context that can monitor schedule and cost performance indexes in projects simultaneously. The EVM detects current project performances and also predicts at completion costs of the project. In this study, employing Interpretive Structural Modelling, interactions which exist among affecting factors on EVM's success are determined. First, all of the practical factors on EVM are determined and categorized into four main clusters; then the most effective ones are separated from the clusters; eventually, ISM is used based on eleven ultimate critical criteria. The results demonstrate that "Instability in the construction market" and "Macroeconomic indicators" are the most influencing factors affecting the EVM. Finally, a novel method for enhancing the performance of conventional EVM is presented. The proposed approach would be highly applicable for engineering managers who are willing to promote the current performance of the systems. Most studies have been previously carried out on the applications of the EVM in terms of improving final cost and total duration elapsed whereas there is not any particular study on the EVM issue which has stated the key factors that influence the EVM and lasting effect on the project performance. It should be noted that the proposed approach can be employed through the life cycle of any project particularly in construction projects.
\end{abstract}

Keywords: Earned Value Management, interpretive structural modelling, schedule and cost performance indexes, CPI, at completion costs.

\section{Introduction}

Nowadays, investment amount in construction projects is experiencing an increasing trend, so the primary concern of engineering and project managers is to accomplish a project on-time, on budget, with an acceptable level of quality (Tabei et al., 2017; Kasravi et al., 2019). In order to reduce the projects duration several kinds of research have been conducted recently (Mahmoudi \& Feylizadeh, 2018; Feylizadeh et al., 2018). Indeed, time and cost and quality are the three critical factors to meet project objectives (Xu et al., 2019). Meanwhile, the EVM assists project managers in identifying factors affecting project objectives in order to monitor the current deviations observed. The EVM is a method which incorporating scope, cost, and schedule in order to measure project performance indexes simultaneously. It is the most frequently utilized method for detecting current performance as well as forecasting at completion costs. The EVM reports variances and performance indices for project costs and schedules as well as predicting project costs and schedule at completion (Acosta, 2015). Despite this, EVM has some shortcomings that have been identified by other scholars. For instance, implementation of EVM is complicated and in some situations it is costly. Also, understanding the main concept of EVM is not an easy task for the project team and project teams are often confused about it. It is interesting to mention that the type of contract may have a negative effect on the EVM especially when the contract is fixed price. EVM uses cost as the main factor for measuring the performance of the projects, which may lead to wrong results. Moreover, EVM does not have a suitable performance that

${ }^{*}$ Corresponding author. E-mail: pmp.mahmoudi@gmail.com 
would allow the quality of the project to be considered (Mahmoudi et al., 2019). The conventional EVM includes 32 criteria as registered in "ANSI/EIA\#748". These criteria are the whole of the requirements which are summarized in five main groups:

- Organization;

- Planning, Scheduling, and Budgeting;

- Accounting Consideration;

- Analysis and Management Report;

- Revisions and Data Maintenance.

In the second group (Planning, Scheduling, and Budgeting) time, cost, risk, and quality are the most critical factors affecting the EVM's success. Moreover, the current study employs literature review and semi-structured interviews for extracting crucial factors in EVM as well. By identifying the critical success factors, top-level managers would control the effects of key factors on EVM's implementation. On the other hand, interpretive structural modelling is a practical methodology for understanding complex conditions. Also, interpretive structural modelling is a well-known method that can identify the relationship among different factors. Therefore, in the current study, these factors are defined and the relationship among all factors has been determined using interpretive structure modelling, which could assist the project manager to enhance the performance of the project undertaken.

\section{Background}

The EVM has been mandated by the U.S. government (Fleming \& Koppelman, 1998). After several years, it became known as the Earned Value Management System (EVMS). According to the research topic, the EVM approach was combined with other mathematical models such as Fuzzy theory (Kuchta, 2005). The main advantage of the fuzzy EVM was it considered uncertainty while measuring the performance of the project. In fact, in real-world situations, the input data cannot be determined precisely and the project team may just provide a membership function for them, hence, employing fuzzy EVM can be useful for measuring the performance of the project. However, the main limitation of fuzzy EVM is finding appropriate membership function for input data when the experts are absent. Meanwile, Mahmoudi et al. (2019) proposed grey EVM that requires simple calculation and can function without expert experience under uncertainty condition. Cioffi (2006) tried to add measurement indicators to the EVM. Indeed, he introduced new notations for EVM while the flexibility of the EVM was enhanced for calculating the performance of the projects in different states. Graham (2007) combined risk management and EVM with each other. Based on his approach, project managers could use the result of the EVM for tracking high-risk elements in projects. Lipke et al. (2009) proposed a web-based system for the financial projections and estimates while it could aid project managers in making an informed decision. Sujatha and Sruthi (2016) tried to facilitate the computation of the performance of the project for project managers. They employed Analytical Network Process (ANP) structure model as a reliable decision-making method to analyze the judgments on all factors involving EVM. Many approaches have been proposed by scholars for improving the performance of the EVM, but the Interpretive Structural Modeling as a research gap has not been employed in the EVM based researches. This study deals with existing gaps in the EVM system, and in order to attain a functional structure in controlling project performance, a combined earned value management and interpretive structural modeling is hereby proposed for engineering managers. As mentioned the main indexes of study are considered time, cost, risk, and quality. The following Table 1 presents the affecting factors set on primary research indexes.

\section{Research methodology}

In this research, an Interpretive Structural Modelling is utilized. The Interpretive Structural Modelling (ISM) is a method used to identify the relationship between specific elements, which define an issue observed. The ISM is also an interactive learning process in which a set of directly related and disparate elements are structured into a comprehensive systematic model.

The basic idea behind ISM is to utilize experts' practical experience and knowledge to construct a multi-level structural model; it was firstly developed in the 1970s (Jayant \& Azhar, 2014). In the ISM methodology, a systematic application of some basic principles of the graph theory is employed in a way that theoretical, and computational influence are exploited to clarify the complex prototype for the relationship among a set of variables. It is primarily proposed as a group learning process, but can also be applied individually. The ISM process enhances unclear, poorly articulated models of systems into a visible, welldefined model. It might act as a tool for imposing order and direction on the complexity of relationships that exist among the whole variables. The main advantages of ISM are presented below (Movahedipour et al., 2017):

- It assists in presenting a complicated system in a simplified manner.

- It yields an interpretation of the fixed objects.

- It facilitates the detection of the structure of a system.

On the other hand, EVM has some limitations and its implementation is complicated in many situations. The main object of the EVM measures the performance of the project while it is a fixed object for projects. Moreover, understanding the main concept of EVM is not easy work for the stakeholders and project teams are often confused about its implementation. Therefore, ISM can contribute to the project team for implementing EVM method.

In this study, after identification of issue's factors, the structural model is constructed. ISM steps are shown in Figure 1.

This study is an empirical research with a descriptive survey. The statistical population of the survey was considered 40 companies. By using Cochran formula, the study's sample for an alpha level a priori at 0.05 (error of 
Table 1. Earned value management influencing factors

\begin{tabular}{|c|c|}
\hline Categories & Influencing factors on EVM \\
\hline Time & $\begin{array}{l}\text { Gross floor area (Dursun \& Stoy, 2012); Number of floors (Torp et al., 2016); Type of building ability (simple/complex) } \\
\text { (Dursun \& Stoy, 2012); Type of facility (housing/commercial/other) (Dursun \& Stoy, 2012); Type of project (buildings/ } \\
\text { civil works) (Dursun \& Stoy, 2012); Changes in specifications of design and material types during construction (Marzouk } \\
\text { \& El-Rasas, 2014); Mistakes and discrepancies in design documents, and defining project tasks (Khoshgoftar et al., 2010); } \\
\text { Material and equipment availability and failure (Bari et al., 2012); Delays in delivery and transfer equipment and raw } \\
\text { material to project site (Akogbe et al., 2013); Slowness of the decision-making process (Polat et al., 2014); The intensive } \\
\text { time set by the owner (Baghdadi \& Kishk, 2015); Project team productivity (Zidane et al., 2015); Delays in contractor's } \\
\text { payment by owner (Sweis et al., 2008); The low accuracy of time estimation of activities (Long et al., 2004); Design } \\
\text { changes by owner or agent during construction (Marzouk \& El-Rasas, 2014); Type of client (public/private) (Dursun } \\
\text { \& Stoy, 2012); Team communication efficacy and team working (Chester, 2005); Using control systems (Patanakul, } \\
\text { 2014); Inadequate contractor experience (Elawi et al., 2016); Poor coordination and communication among parties } \\
\text { and conflicts among project participants (Zidane et al., 2015); Changes in building codes (Khodeir \& Mohamed, 2015); } \\
\text { Changes in laws and regulations (Wael et al., 2007); Inflation and fluctuations in material price, equipment, and salary } \\
\text { (Baghdadi \& Kishk, 2015); Political and economic sanctions and lack of materials (Baghdadi \& Kishk, 2015). }\end{array}$ \\
\hline Cost & $\begin{array}{l}\text { Inappropriate price bid by the employer (Muya et al., 2013); Change orders/Scope changes by stakeholders (Ahsan \& } \\
\text { Gunawan, 2010); Construction mistakes and defective work (Ahsan \& Gunawan, 2010); Lack of database in estimating } \\
\text { activity duration and resources (Aziz \& Abdel-Hakam, 2016); Incomplete design and ambiguous documents (Toh et al., } \\
\text { 2012); Poor construction planning (Dursun \& Stoy, 2012); Variations in the sequencing of tasks (Frimpong, 2003); Poor } \\
\text { experience of stakeholders (Dursun \& Stoy, 2012); Complexity in cost estimating and weak technical studies (Muya et al., } \\
\text { 2013); Lack of access to project information (Frimpong, 2003); Poor cost control (Dursun \& Stoy, 2012); Obtaining } \\
\text { permits from the municipality (Aziz \& Abdel-Hakam, 2016); Changes in laws and regulations during construction (Aziz } \\
\text { \& Abdel-Hakam, 2016); Termination of the agreement and contract based on public and private conditions (Aziz \& } \\
\text { Abdel-Hakam, 2016); Inflation (Baghdadi \& Kishk, 2015); Disproportion between inflation rate and adjustment index } \\
\text { (Ahsan \& Gunawan, 2010); Macroeconomic indicators such as recessions, inflation, producer price index, raw material } \\
\text { prices and labor (Aziz \& Abdel-Hakam, 2016); Economic conditions (Muya et al., 2013). }\end{array}$ \\
\hline Risk & $\begin{array}{l}\text { Improper budgeting \& contingencies (Khodeir \& Mohamed, 2015); Damage of equipment and materials in storage (Aziz } \\
\text { \& Abdel-Hakam, 2016); Slow delivery of materials and materials availability (Baghdadi \& Kishk, 2015); Contractor } \\
\text { selection based on a low bid price regardless of technical ability (Aziz \& Abdel-Hakam, 2016); Currency fluctuation } \\
\text { (Baghdadi \& Kishk, 2015); Inadequate scope (Baghdadi \& Kishk, 2015); Changes or errors in design (Aziz \& Abdel- } \\
\text { Hakam, 2016); Design details unclear \& inadequate (Aziz \& Abdel-Hakam, 2016); Errors committed during field } \\
\text { construction (Baghdadi \& Kishk, 2015); Risks related to labor (injuries, disputes, little motivation, absenteeism...) } \\
\text { (Aziz \& Abdel-Hakam, 2016); Labor strikes (Baghdadi \& Kishk, 2015); Uncertainty in project (Patanakul, 2014)/ Low } \\
\text { labor productivity (Marzouk \& El-Rasas, 2014); Shortage of skilled laborers and Equipment productivity (Aziz \& Abdel- } \\
\text { Hakam, 2016). }\end{array}$ \\
\hline Quality & $\begin{array}{l}\text { Design quality regarding details (Dursun \& Stoy, 2012); Low quality of construction materials (Aziz \& Abdel-Hakam, } \\
\text { 2016); Ineffective scheduling of project (Aziz \& Abdel-Hakam, 2016); Mistakes and discrepancies in contract documents } \\
\text { (Aziz \& Abdel-Hakam, 2016); Lack of experience of consulting in construction projects (Dursun \& Stoy, 2012); Quality } \\
\text { assurance/control and application of quality control based on foreign specifications (Patanakul, 2014); Instability in } \\
\text { construction market (Muya et al., 2013); Insufficient available utilities on site, Geological problems on site (Aziz \& } \\
\text { Abdel-Hakam, 2016); Environmental concerns and restrictions (Aziz \& Abdel-Hakam, 2016). }\end{array}$ \\
\hline
\end{tabular}

5\%) was computed for 35 samples observed. After reviewing all elements affecting the earned value management, 73 factors were identified and listed in four main indexes as are presented in Table 1 . Then all the factors were revised, and similarities were then eliminated. Afterward, a questionnaire was distributed among experts in the field of the project management system to identify the most critical factors that were derived in the last step. It should be noted that according to the responses of the projects' experts, the following elements are the most important affecting factors on earned value management's success.

In this study, to identify the contextual relationship among the criteria, the second questionnaire was designed to compare pairwise elements. According to the initial questionnaire sample size, 13 experts were considered to investigate pair-wise comparison. Considering the four main indexes of the earned value management (time, cost, risk, quality), factors were derived from the initial questionnaire analysis; for time index, the first four factors of the Table 2; cost index, the first three factors; risk index, the first three factors, and for quality index, the first factor was considered in the ISM model. In Table 3, all the elements were taken from Table 2 except Factor 10. Factor 10 was obtained based on expert judgments rather than the literature survey. Based on the framework presented in Figure 1, the steps of data analysis in ISM are summarized as follows:

Step 1: The variables affecting Earned Value Management are identified. After exhaustively reviewing the existing literature and interviewing 13 experts, eleven criteria are identified and reported in the previous section.

Step 2: Structural self-interaction matrix. The following structural self-interaction matrix is obtained from the experts' judgments (see Table 2).

Step 3: Reachability matrix (Table 4). 


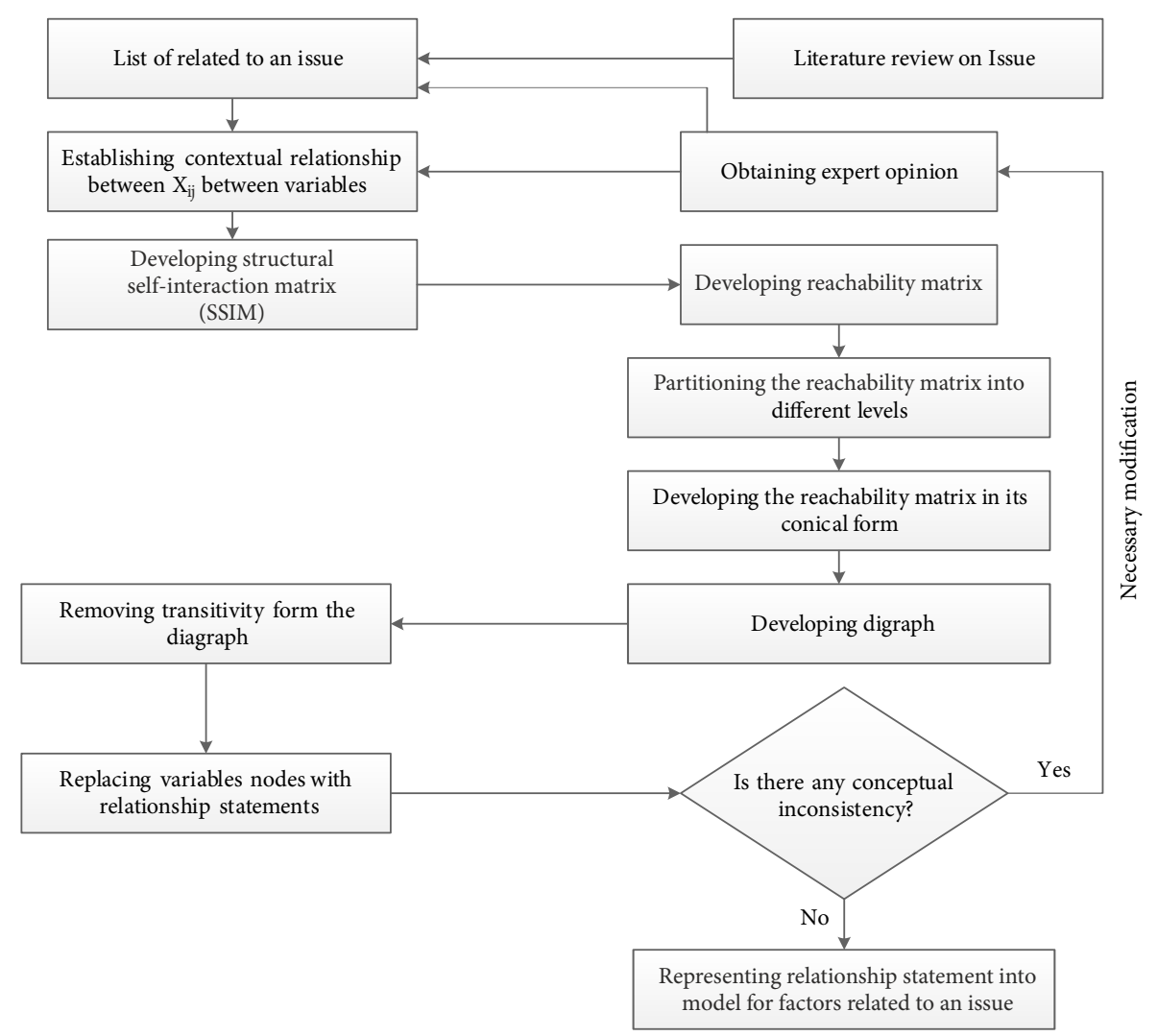

Figure 1. Flow diagram for preparing ISM model (Attri et al., 2013)

Table 2. Most important affecting factors on EVM

\begin{tabular}{|c|c|c|c|c|c|c|c|c|c|c|c|}
\hline & $\mathrm{C} 1$ & $\mathrm{C} 2$ & $\mathrm{C} 3$ & $\mathrm{C} 4$ & $\mathrm{C} 5$ & C6 & C7 & $\mathrm{C} 8$ & C9 & $\mathrm{C} 10$ & C11 \\
\hline 节 & 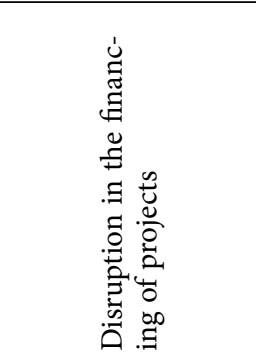 & 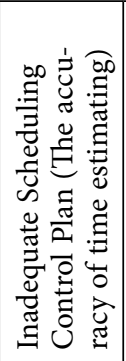 & 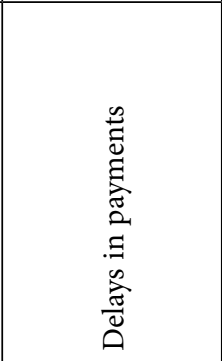 & 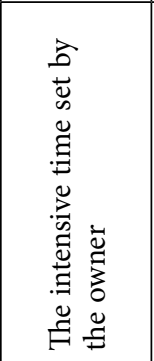 & 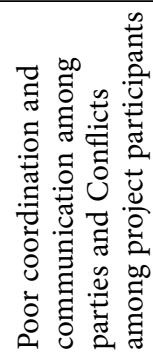 & 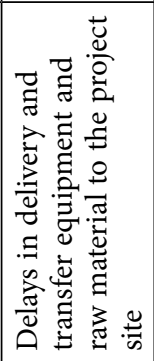 & 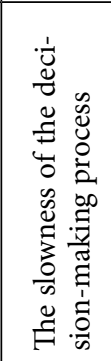 & 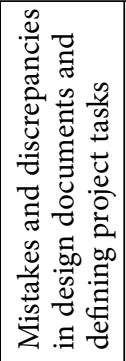 & 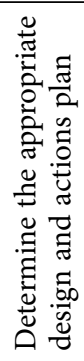 & 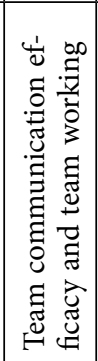 & 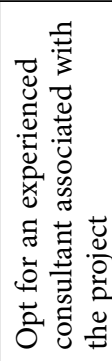 \\
\hline $\begin{array}{l}\overrightarrow{0} \\
\dot{\theta}\end{array}$ & 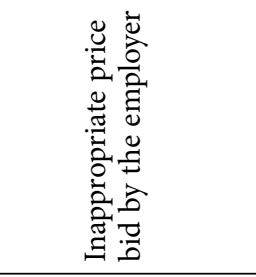 & 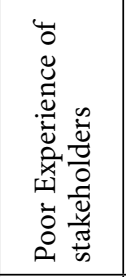 & 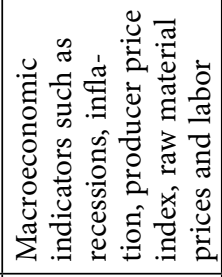 & 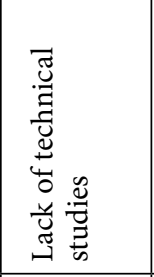 & 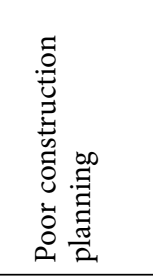 & 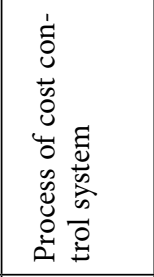 & 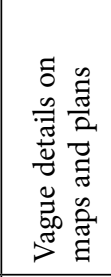 & & & & \\
\hline 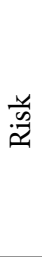 & 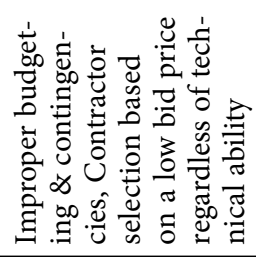 & 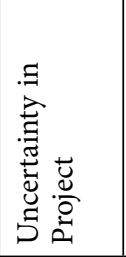 & 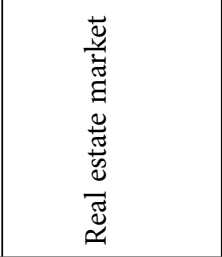 & 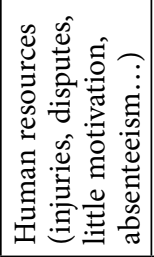 & 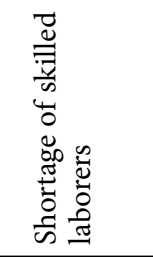 & 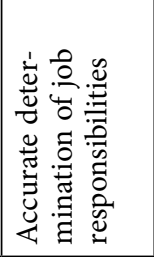 & 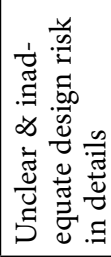 & & & & \\
\hline 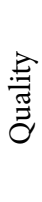 & 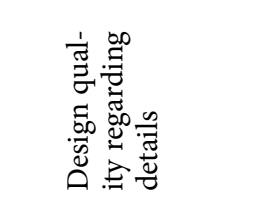 & 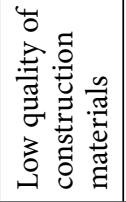 & 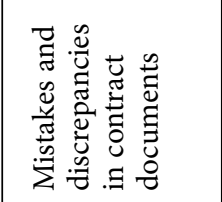 & & & & & & & & \\
\hline
\end{tabular}


Table 3. Self-interaction matrix

\begin{tabular}{|c|c|c|c|c|c|c|c|c|c|c|c|c|}
\hline \multicolumn{2}{|r|}{ Factors } & 11 & 10 & 9 & 8 & 7 & 6 & 5 & 4 & 3 & 2 & 1 \\
\hline 1 & $\begin{array}{l}\text { Macroeconomic indicators such as recessions, inflation, producer } \\
\text { price index, raw material prices and labor }\end{array}$ & $\mathrm{O}$ & $\mathrm{V}$ & $\mathrm{V}$ & $\mathrm{O}$ & $\mathrm{O}$ & $\mathrm{O}$ & $\mathrm{O}$ & $\mathrm{O}$ & $\mathrm{V}$ & $\mathrm{V}$ & \\
\hline 2 & Inappropriate real estate market conditions & $\mathrm{O}$ & $\mathrm{O}$ & $\mathrm{O}$ & $\mathrm{O}$ & $\mathrm{V}$ & $\mathrm{V}$ & $\mathrm{V}$ & $\mathrm{V}$ & $\mathrm{V}$ & & \\
\hline 3 & Inappropriate price bid by the employer & $\mathrm{O}$ & $\mathrm{V}$ & $\mathrm{V}$ & $\mathrm{O}$ & $\mathrm{O}$ & $\mathrm{V}$ & $\mathrm{V}$ & $\mathrm{V}$ & & & \\
\hline 4 & $\begin{array}{l}\text { Risk-Contractor selection based on a low price bid regardless } \\
\text { of technical ability }\end{array}$ & $\mathrm{X}$ & $\mathrm{V}$ & $\mathrm{V}$ & $\mathrm{O}$ & $\mathrm{O}$ & $\mathrm{V}$ & $\mathrm{V}$ & & & & \\
\hline 5 & Uncertainty in Project & A & $\mathrm{X}$ & $\mathrm{V}$ & $\mathrm{O}$ & $\mathrm{O}$ & $\mathrm{O}$ & & & & & \\
\hline 6 & Intensive time set by the owner & A & $\mathrm{V}$ & $\mathrm{V}$ & $\mathrm{V}$ & $\mathrm{V}$ & \multicolumn{6}{|c|}{ Legend } \\
\hline 7 & Poor Scheduling Control Plan & A & $\mathrm{V}$ & $\mathrm{V}$ & $\mathrm{V}$ & \multirow{2}{*}{\multicolumn{7}{|c|}{$\begin{array}{l}\text { A: Indicates a relation from factor } j \\
\text { to factor } i\end{array}$}} \\
\hline 8 & Poor design (Inappropriate design quality regarding details) & A & $\mathrm{X}$ & $\mathrm{V}$ & & & & & & & & \\
\hline 9 & Disruption in the financing of projects (delay in payments) & A & $\mathrm{X}$ & & & \multicolumn{7}{|c|}{$\begin{array}{l}\text { V: Indicates a relation from factor } i \\
\text { to factor } j\end{array}$} \\
\hline 10 & Changes in projects (scope, plans, and design) & A & & & & \multirow{2}{*}{\multicolumn{7}{|c|}{$\begin{array}{l}\mathrm{X} \text { : Indicates the relation between } \\
\text { factors } i \text { and } j \text { at the same time } \\
\text { O: No relation between } i \text { and } j\end{array}$}} \\
\hline 11 & Poor experience of stakeholders & & & & & & & & & & & \\
\hline
\end{tabular}

Table 4. Initial reachability matrix

\begin{tabular}{|c|c|c|c|c|c|c|c|c|c|c|c|}
\hline $\begin{array}{l}\mathscr{0} \\
\stackrel{0}{0} \\
\tilde{\Xi} \\
\end{array}$ & $\vec{u}$ & $\mathcal{U}$ & 3 & U & 3 & ن & $\hat{U}$ & $\stackrel{\infty}{0}$ & $\bigcup^{\infty}$ & $\stackrel{\circ}{u}$ & $\bar{u}$ \\
\hline $\mathrm{C} 1$ & 1 & 0 & 1 & 0 & 0 & 0 & 0 & 0 & 1 & 1 & 0 \\
\hline $\mathrm{C} 2$ & 0 & 1 & 1 & 1 & 1 & 1 & 1 & 0 & 0 & 0 & 0 \\
\hline C3 & 0 & 0 & 1 & 1 & 1 & 1 & 0 & 0 & 1 & 1 & 0 \\
\hline $\mathrm{C} 4$ & 0 & 0 & 0 & 1 & 1 & 1 & 0 & 0 & 1 & 1 & 0 \\
\hline C5 & 0 & 0 & 0 & 0 & 1 & 0 & 0 & 0 & 1 & 1 & 0 \\
\hline C6 & 0 & 0 & 0 & 0 & 0 & 1 & 1 & 1 & 1 & 1 & 0 \\
\hline C7 & 0 & 0 & 0 & 0 & 0 & 0 & 1 & 1 & 1 & 1 & 0 \\
\hline C8 & 0 & 0 & 0 & 0 & 0 & 0 & 0 & 1 & 1 & 1 & 0 \\
\hline C9 & 0 & 0 & 0 & 0 & 0 & 0 & 0 & 0 & 1 & 1 & 0 \\
\hline C10 & 0 & 0 & 0 & 0 & 0 & 0 & 0 & 1 & 1 & 1 & 0 \\
\hline C11 & 0 & 0 & 0 & 0 & 1 & 1 & 1 & 1 & 1 & 1 & 1 \\
\hline
\end{tabular}

It should be noted that the substitution of 1 and 0 are as per the rules as follows:

- if $(i, j)$ entry is A, then $(i, j)$ entry in the reachability matrix becomes 0 and $(j, i)$ entry becomes 1 ;

- if $(i, j)$ entry is $\mathrm{V}$, then $(i, j)$ entry in the reachability matrix becomes 1 and $(j, i)$ entry becomes 0 ;

- if $(i, j)$ entry is $\mathrm{X}$, then $(i, j)$ entry in the reachability matrix becomes 1 and $(j, i)$ entry becomes 1 as well;

- if $(i, j)$ entry is $\mathrm{O}$, then $(i, j)$ entry in the reachability matrix becomes 0 and $(j, i)$ entry becomes 0 as well.

Transitivity is also a distinction made as per the underlying assumption in the ISM, which states that if criteria $\mathrm{X}$ is related to $\mathrm{Y}$ and $\mathrm{Y}$ is related to $\mathrm{Z}$, then $\mathrm{X}$ is mainly related to $Z$. The final reachability matrix $M$ is determined by Eqn (1). The driving and dependence power are de-
Table 5 . The final reachability matrix

\begin{tabular}{|c|c|c|c|c|c|c|c|c|c|c|c|c|}
\hline 苞 & $\vec{U}$ & $\widetilde{U}$ & 3 & J & 3 & 8 & $\hat{U}$ & 0 & $\stackrel{\infty}{0}$ & 은 & $\exists$ & 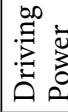 \\
\hline $\mathrm{C} 1$ & 1 & 1 & 1 & 1 & 1 & 1 & 0 & 1 & 1 & 1 & 0 & 9 \\
\hline $\mathrm{C} 2$ & 1 & 1 & 1 & 1 & 1 & 1 & 1 & 1 & 1 & 1 & 0 & 10 \\
\hline C3 & 0 & 0 & 1 & 1 & 1 & 1 & 1 & 1 & 1 & 1 & 0 & 8 \\
\hline $\mathrm{C} 4$ & 0 & 0 & 0 & 1 & 1 & 1 & 1 & 1 & 1 & 1 & 0 & 7 \\
\hline C5 & 0 & 0 & 0 & 0 & 1 & 0 & 1 & 1 & 1 & 1 & 0 & 5 \\
\hline C6 & 0 & 0 & 0 & 0 & 0 & 1 & 1 & 1 & 1 & 1 & 0 & 5 \\
\hline C7 & 0 & 0 & 0 & 0 & 0 & 0 & 1 & 1 & 1 & 1 & 0 & 4 \\
\hline C8 & 0 & 0 & 0 & 0 & 0 & 0 & 0 & 1 & 1 & 1 & 0 & 3 \\
\hline C9 & 0 & 0 & 0 & 0 & 0 & 0 & 0 & 1 & 1 & 1 & 0 & 3 \\
\hline C10 & 0 & 0 & 0 & 0 & 0 & 0 & 0 & 1 & 1 & 1 & 0 & 3 \\
\hline C11 & 0 & 0 & 0 & 0 & 1 & 1 & 1 & 1 & 1 & 1 & 1 & 7 \\
\hline $\begin{array}{l}\text { Dependence } \\
\text { Power }\end{array}$ & 2 & 2 & 3 & 4 & 6 & 6 & 7 & 11 & 11 & 11 & 1 & \\
\hline
\end{tabular}

termined by detecting numbers of the variable. The final reachability matrix is shown in Table 5 .

$$
\begin{aligned}
& M=D+I \\
& M^{*}=M^{k}=M^{k+1}, k>1 .
\end{aligned}
$$

Step 4: Level partitions. When the reachability matrix is expanded, the antecedent and reachability sets are formed for each factor. The Reachability set includes all the factors driven by the variable under consideration. An intersection set is constituted by the common elements of both of these sets. If the elements corresponding to the reachability and intersection set for each identified factor become the same, the element moves to the top-level factor in the interpretive structural modeling (ISM) hierarchy. This result is determined by Eqn (2). This top-level factor is then 
separated from other factors. This level partitioning process is repeated until all levels are obtained. To summarize, in this section merely the output of the first (Table 6) and the final (Table 7) iterations is displayed.

$$
\mathrm{R}\left(\mathrm{c}_{\mathrm{j}}\right) \cap \mathrm{A}\left(\mathrm{c}_{\mathrm{j}}\right)=\mathrm{R}\left(\mathrm{c}_{\mathrm{j}}\right), \forall \mathrm{c}_{\mathrm{j}} \in \mathrm{C} .
$$

Step 5: Building the ISM-based model. By using the final reachability matrix (Table 5), the structural model is now generated using vertices or nodes and lines of edges. If there is a relation between the criteria $j$ and $i$, this matter is shown by an arrow connecting $i$ to $j$. This graph is called a directed graph or digraph. After removing the transitivities, the digraph is finally transformed into ISM as shown in Figure 2. The most important factors related to EVM were extracted earlier using expert opinion. Moreover, ISM is a well-known method which can identify the relationship among different factors. Therefore, for the variables defined in this research, the ISM model developed controls practical factors on earned value management. According to the various factors levels, the EVM's elements structure is set up, as shown in Figure 2.

According to Figure 2, it is observed that macroeconomic indicators and inappropriate real estate market conditions are significant factors affecting the Earned Value Management's success. Inadequate real estate market conditions depend heavily on the Macroeconomic indicators. These two factors respectively are as the cost and risk criteria that were obtained from EVM's indicators. However, these two factors are environmental factors affecting the Earned Value Management, which cannot always be controlled. These two criteria influence Inappropriate price bid by the employer as shown in the level 5 and this criterion leads to Risk-Contractor Selection in level 4, on the other hand, the Poor Experience of Stakeholders and Risk-Contractor Selection have interactions related to each other. These criteria form the base level of ISM hierarchy due to their durable driving power and thus should be treated as specific criteria. The driver power of Risk-Contractor Selection and Poor Experience of Stakeholders lead to Uncertainty in the project and Intensive time set by the owner at the fifth level of the ISM model.
Table 7. Iteration 6

\begin{tabular}{|c|c|c|c|c|}
\hline Factors & $\begin{array}{c}\text { Reachability } \\
\text { set }\end{array}$ & $\begin{array}{c}\text { Antecedent } \\
\text { set }\end{array}$ & $\begin{array}{c}\text { Intersection } \\
\text { set }\end{array}$ & Level \\
\hline $\mathrm{c} 1$ & 1,2 & 1,2 & 1,2 & 6 \\
\hline $\mathrm{c} 2$ & 1,2 & 1,2 & 1,2 & 6 \\
\hline
\end{tabular}

In the resulting ISM model, Poor Scheduling Control Plan is impacted from level 3 in which its driven power leads to its direct influence on the criteria in the top level of the model, namely, Changes in projects (scope, plans, and design), Poor design (Inappropriate design quality in terms of details) and Disruption in the financing of projects (delay in payments) were found to play the least influential role as compared with the other 8 factors. These top three factors of the ISM have a direct effect on the EVM systems by changes in the time, cost, risk, and quality of the project. Practitioners and decision-makers should state priorities while addressing these criteria to achieve success in project management. To achieve this, we should find out the power of factors to identify the driver power and the dependence power of model's item, using MICMAC analysis that is presented in the following.

\section{MICMAC analysis}

MICMAC refers to Matrice d'Impacts Croisés Multiplication Appliqués à un Classement (cross-impact matrix multiplication applied to classification) (Šoltés \& Gavurová, 2013). The purpose of MICMAC analysis is evaluating the drive power and dependence power of influencing factors (Attri, 2013). The elements are classified into four categories (Figure 3). The first category consists of the "autonomous factors" that show weak driver power and weak dependence. These factors are relatively disconnected from the system. The second cluster consists of the "dependent factors" that have weak driver power but show high dependency. The third cluster has the "linkage factors" that imply strong driving power with high dependence. These factors are unsteady in the fact that any action on these factors will affect others. The fourth cluster includes the

Table 6. Iteration 1

\begin{tabular}{|c|c|c|c|c|}
\hline Factors & Reachability set & Antecedent set & Intersection set & 1,2 \\
\hline C1 & $1,2,3,4,5,6,8,9,10$ & 1,2 & 1,2 \\
\hline C2 & $1,2,3,4,5,6,7,8,9,10$ & 1,2 & 3 & 4 \\
\hline C3 & $3,4,5,6,7,8,9,10$ & $1,2,3$ & 5 & 6 \\
\hline C4 & $4,5,6,7,8,9,10$ & $1,2,3,4$ & 7 & $8,9,10$ \\
\hline C5 & $5,7,8,9,10$ & $1,2,3,4,5,11$ & $8,9,10$ \\
\hline C6 & $6,7,8,9,10$ & $1,2,3,4,6,11$ & 1 \\
\hline C8 & $7,8,9,10$ & $2,3,4,5,6,7,11$ & $8,9,10$ & 1 \\
\hline C9 & $8,9,10$ & $1,2,3,4,5,6,7,8,9,10,11$ & 1 \\
\hline C10 & $8,9,10$ & $1,2,3,4,5,6,7,8,9,10,11$ & 1 \\
\hline
\end{tabular}




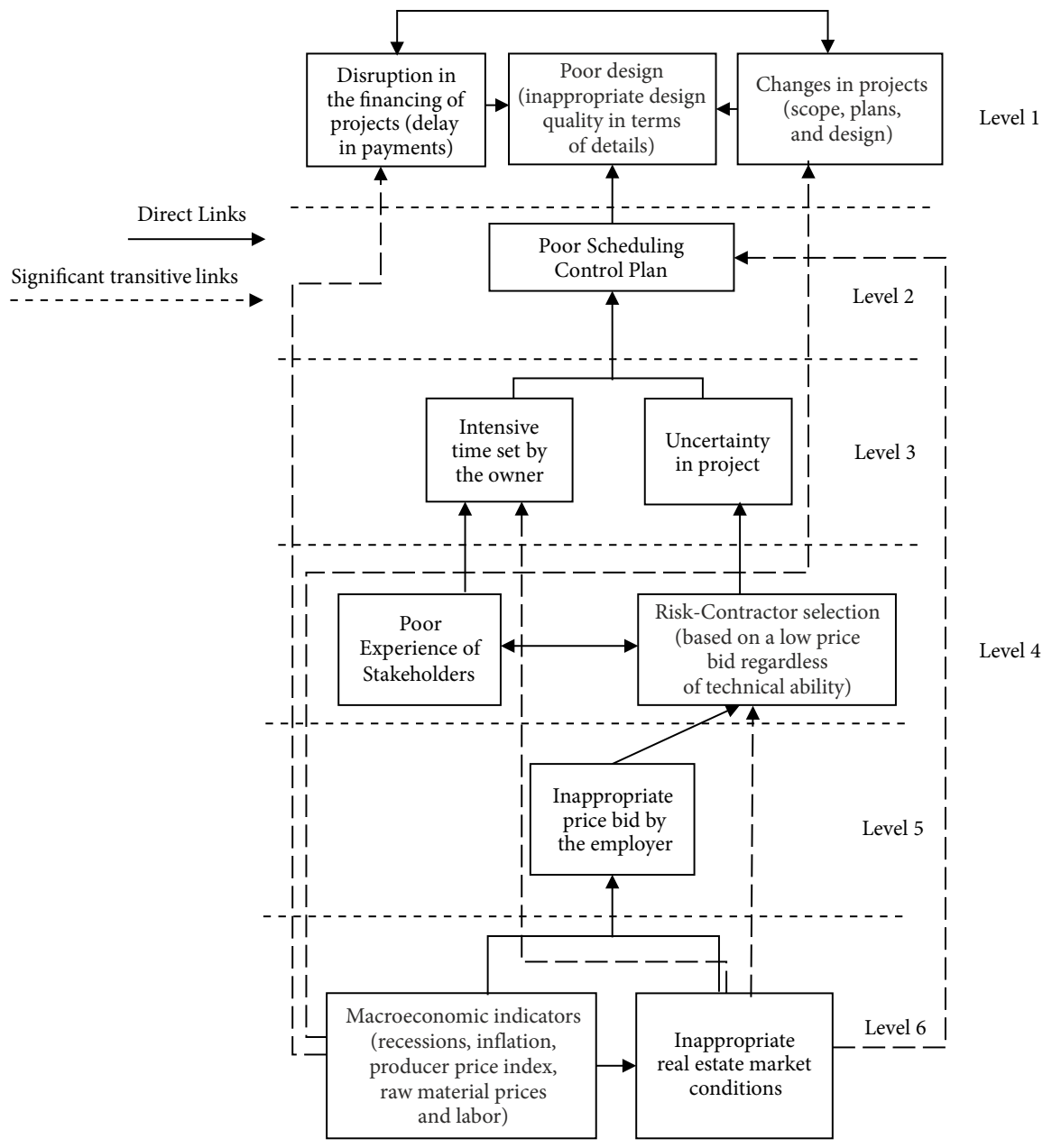

Figure 2. Interpretive structural modelling for EVM

"independent factors" having strong driving power, yet weak dependency. It is observed that a variable with an extreme driving power called the key variable falls into the group of independent or linkage factors (Attri et al., 2013). The driving power and the dependence of each of

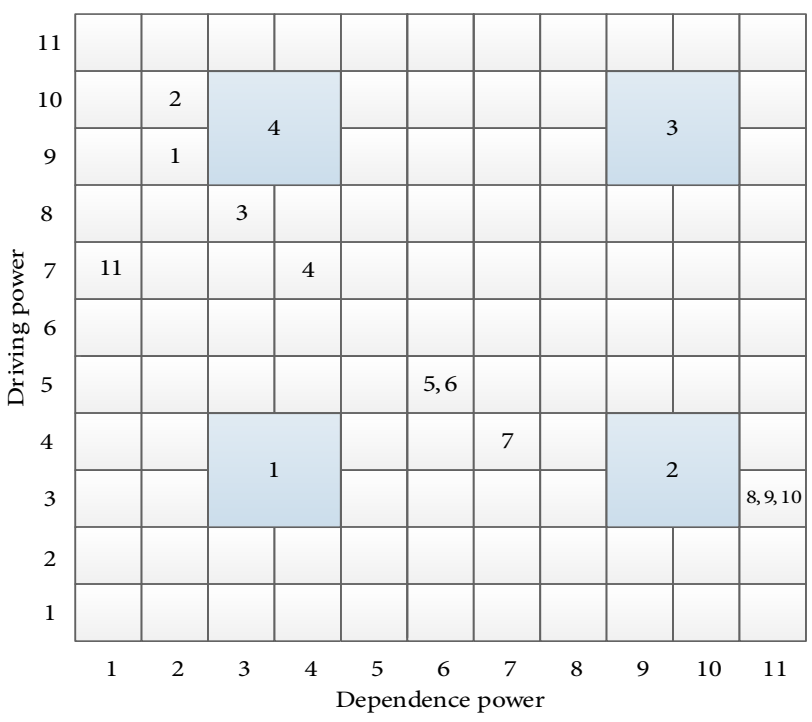

Figure 3. MICMAC analysis of the EVM these factors are shown in Table 5. In Table 5, an entry of " 1 " along the columns and rows illustrates the dependence and driving power, respectively. Likewise, the driver power-dependence diagram is constructed, which is shown in Figure 3. As an illustration, it is observed from Table 2 that factors $8,9,10$ have dependence power of 11 and driver power of 3 , which shows that the other 8 factors influence them. Most of the research model factors are in the Independent factors cluster. In fact, any changes in these factors' cluster would influence on EVM system.

\section{Findings and discussions}

In this study, in order to determine the most efficient factors, four main indexes (time, cost, risk, and quality) are developed and analyzed. Then, according to the share number of each index, the main factors are determined. The ISM method is utilized to structure these representative factors in a hierarchy, which is further categorized into different clusters in a two-dimensional (driving-power/dependence-power) diagram by applying the MICMAC technique. It has been discovered that inappropriate real estate market conditions (C2) and Macroeconomic indicators (C2) are the most influential factors that affect on EVM and their indicators and have reliable driver power 
in EVM system. On the other hand, Changes in projects (C10), Poor design (inappropriate design quality in terms of details) (C8) and Disruption in the financing of projects (delay in payments) (C9) are affected by the other factors in the model which means they have strong dependencies on them and leads to having a direct effect on the EVM and performance index like SPI and CPI. Therefore, by developing a functional model the negative consequences of these factors can be monitored and reduced when the EVM technique is used in the project management context. In the following, this issue is noted. As a result, the "Changes in the project", "Disruption in the financing of the project" and "Poor design" are the factors that directly affect EVM, and its input data (Actual Cost, Planned Value, and Earned Value). Project manager at the time of project execution along with other factors in ISM model should focus on these three factors and determine the impact and intensity of the occurrence in EVM's input data (AC, PV, EV). Besides, these input data are recomputed to achieve the project performance aims and SPI $>1$ and CPI $>1$ that will lead to the project being completed on time at the lowest cost, risk, and with the best quality. It is interesting to note that the project team can determine the impact of these crucial factors on time and cost. SPI and CPI are useful indexes for measuring the effects of each element while they can be calculated for an activity or the whole project. It should be mentioned that the proposed approach can be applied to any projects.

\section{Concluding remarks and further recommendations}

Understanding the factors and challenges to the implementation of an earned value management system and the structural relationship between these elements can lead to better recognition of the complexity of system implementation and subsequently, can lead to achieving the project performance aims. Despite extensive studies done on the Earned Value Management, most of these research studies are just limited to improving the estimation and forecasting of time and cost project, but the affecting factors of the EVM and relationship between these items have never been investigated. The current research attempts to fill this gap in the EVM's literature by studying and identifying the practical factors on the EVM system and the interactive relationship among these factors using Interpretive structural model in this issue, and a novel method for controlling the elements affecting the Earned Value Management is proposed. The proposed approach promotes the performance of conventional EVM. Finally, in this research, the relationship model among the identified EVM factors has not been statistically validated.

The modeling procedure given in this paper can therefore be implemented in construction projects throughout its life cycle. As the EVM is known as an early warning mechanism, applying this procedure at the early stage of the project is mostly recommended. Structural equation modeling (SEM), could also be further discussed as linear structural relationship approach has the capability of testing the validity of such hypothetical models. Thus, this method can be used in future studies to check the validity of this model. ISM is a tool which can be helpful to develop an initial model whereas SEM has the capability of statistically testing an already established proposed theoretical model. Hence, it has been suggested that future research may be targeted to develop the initial model through ISM.

\section{Acknowledgements}

This work was supported by the National Natural Science Foundation of China under Grant [NSFC-71771052 and 71372199].

\section{Funding}

This work was supported by the National Natural Science Foundation of China under Grant [NSFC-71771052 and 71372199].

\section{Author contributions}

All authors have contributed equally.

\section{Disclosure statement}

The authors declare that they have no conflict of interest in this article.

\section{References}

Acosta, H. C. (2015). Linking cost of quality (COQ) with department of defense (DoD) contractors earned value management system (EVMS) cost reduction efforts. California State University.

Ahsan, K., \& Gunawan, I. (2010). Analysis of cost and schedule performance of international development projects. International Journal of Project Management, 28(1), 68-78. https://doi.org/10.1016/j.ijproman.2009.03.005

Akogbe, R. K. T., Feng, X., \& Zhou, J. (2013). Importance and ranking evaluation of delay factors for development construction projects in Benin. KSCE Journal of Civil Engineering, 17(6), 1213-1222. https://doi.org/10.1007/s12205-013-0446-2

Attri, R., Dev, N., \& Sharma, V. (2013). Interpretive structural modelling (ISM) approach: An overview. Research Journal of Management Sciences, 2(2), 3-8.

Aziz, R. F., \& Abdel-Hakam, A. A. (2016). Exploring delay causes of road construction projects in Egypt. Alexandria Engineering Journal, 55(2), 1515-1539. https://doi.org/10.1016/j.aej.2016.03.006

Baghdadi, A., \& Kishk, M. (2015). Saudi Arabian aviation construction projects: Identification of risks and their consequences. Procedia Engineering, 123, 32-40. https://doi.org/10.1016/j.proeng.2015.10.054 
Bari, N. A. A., Yusuff, R., Ismail, N., Jaapar, A., \& Ahmad, R. (2012). Factors influencing the construction cost of industrialised building system (IBS) projects. Procedia-Social and Behavioral Sciences, 35, 689-696.

https://doi.org/10.1016/j.sbspro.2012.02.138

Chester, M., \& Hendrickson, C. (2005). Cost impacts, scheduling impacts, and the claims process during construction. Journal of Construction Engineering and Management, 131(1), 102-107. https://doi.org/10.1061/(ASCE)0733-9364(2005)131:1(102)

Cioffi, D. F. (2006). Designing project management: A scientific notation and an improved formalism for earned value calculations. International Journal of Project Management, 24(2), 136-144. https://doi.org/10.1016/j.ijproman.2005.07.003

Dursun, O., \& Stoy, C. (2012). Determinants of construction duration for building projects in Germany. Engineering, Construction and Architectural Management, 19(4), 444-468. https://doi.org/10.1108/09699981211237139

Elawi, G. S. A., Algahtany, M., \& Kashiwagi, D. (2016). Owners' perspective of factors contributing to project delay: Case studies of road and bridge projects in Saudi Arabia. Procedia Engineering, 145, 1402-1409.

https://doi.org/10.1016/j.proeng.2016.04.176

Feylizadeh, M. R., Mahmoudi, A., Bagherpour, M., \& Li, D. F. (2018). Project crashing using a fuzzy multi-objective model considering time, cost, quality and risk under fast tracking technique: A case study. Journal of Intelligent \& Fuzzy Systems, 35(3), 3615-3631. https://doi.org/10.3233/JIFS-18171

Fleming, Q. W., \& Koppelman, J. M. (1998, July). Earned value project management: A powerful tool for software projects. The Journal of Defense Software Engineering, 19-23.

http://anclasol.com/AS/e-books/ing/FREEeBooks/earned $\% 20$ value\%20project\%20management.pdf

Frimpong, Y., Oluwoye, J., \& Crawford, L. (2003). Causes of delay and cost overruns in construction of groundwater projects in a developing countries; Ghana as a case study. International Journal of Project Management, 21(5), 321-326. https://doi.org/10.1016/S0263-7863(02)00055-8

Graham, D. R. (2007, March). Using cost-risk to connect cost estimating and earned value management (EVM). In 2007 IEEE Aerospace Conference. Big Sky, MT, USA. https://doi.org/10.1109/AERO.2007.353026

Jayant, A., \& Azhar, M. (2014). Analysis of the barriers for implementing green supply chain management (GSCM) practices: An interpretive structural modeling (ISM) approach. Procedia Engineering, 97, 2157-2166.

https://doi.org/10.1016/j.proeng.2014.12.459

Kasravi, M., Mahmoudi, A., \& Feylizadeh, M. R. (2019). A novel algorithm for solving resource-constrained project scheduling problems: a case study. Journal of Advances in Management Research, 16(2), 194-215.

https://doi.org/10.1108/JAMR-03-2018-0033

Khodeir, L. M., \& Mohamed, A. H. M. (2015). Identifying the latest risk probabilities affecting construction projects in Egypt according to political and economic variables. From January 2011 to January 2013. HBRC Journal, 11(1), 129-135. https://doi.org/10.1016/j.hbrcj.2014.03.007

Khoshgoftar, M., Bakar, A. H. A., \& Osman, O. (2010). Causes of delays in Iranian construction projects. International Journal of Construction Management, 10(2), 53-69. https://doi.org/10.1080/15623599.2010.10773144
Kuchta, D. (2005). Fuzzyfication of the earned value method. WSEAS Transactions on Systems, 4(12), 2222-2229.

Lipke, W., Zwikael, O., Henderson, K., \& Anbari, F. (2009). Prediction of project outcome: The application of statistical methods to earned value management and earned schedule performance indexes. International Journal of Project Management, 27(4), 400-407.

https://doi.org/10.1016/j.ijproman.2008.02.009

Long, N. D., Ogunlana, S., Quang, T., \& Lam, K. C. (2004). Large construction projects in developing countries: a case study from Vietnam. International Journal of Project Management, 22(7), 553-561.

https://doi.org/10.1016/j.ijproman.2004.03.004

Mahmoudi, A., \& Feylizadeh, M. R. (2018). A grey mathematical model for crashing of projects by considering time, cost, quality, risk and law of diminishing returns. Grey Systems: Theory and Application, 8(3), 272-294.

https://doi.org/10.1108/GS-12-2017-0042

Mahmoudi, A., Bagherpour, M., \& Javed, S. A. (2019). Grey earned value management: Theory and applications. IEEE Transactions on Engineering Management, 1-19. https://doi.org/10.1109/TEM.2019.2920904

Marzouk, M. M., \& El-Rasas, T. I. (2014). Analyzing delay causes in Egyptian construction projects. Journal of Advanced Research, 5(1), 49-55. https://doi.org/10.1016/j.jare.2012.11.005

Movahedipour, M., Zeng, J., Yang, M., \& Wu, X. (2017). An ISM approach for the barrier analysis in implementing sustainable supply chain management: An empirical study. Management Decision, 55(8), 1824-1850.

https://doi.org/10.1108/MD-12-2016-0898

Muya, M., Kaliba, C., Sichombo, B., \& Shakantu, W. (2013). Cost escalation, schedule overruns and quality shortfalls on construction projects: The case of Zambia. International Journal of Construction Management, 13(1), 53-68. https://doi.org/10.1080/15623599.2013.10773205

Patanakul, P. (2014). Managing large-scale IS/IT projects in the public sector: Problems and causes leading to poor performance. The Journal of High Technology Management Research, 25(1), 21-35. https://doi.org/10.1016/j.hitech.2013.12.004

Polat, G., Okay, F., \& Eray, E. (2014). Factors affecting cost overruns in micro-scaled construction companies. Procedia Engineering, 85, 428-435.

https://doi.org/10.1016/j.proeng.2014.10.569

Šoltés, V., \& Gavurová, B. (2013). Application of the cross impact matrix method in problematic phases of the Balanced Scorecard system in private and public sector. Journal of Applied Economic Sciences, 8(1), 99-119.

Sujatha, E. R. \& Sruthi, N. (2016). Application of earned value management to compute the project performance using analytical network process. Jordan Journal of Civil Engineering, $159,1-12$.

Sweis, G., Sweis, R., Hammad, A. A., \& Shboul, A. (2008). Delays in construction projects: The case of Jordan. International Journal of Project Management, 26(6), 665-674. https://doi.org/10.1016/j.ijproman.2007.09.009

Tabei, S. M. A., Bagherpour, M., \& Mahmoudi, A. (2017). Application of fuzzy modelling to predict construction projects cash flow. Periodica Polytechnica Civil Engineering, 63(2), 647-659. https://doi.org/10.3311/PPci.13402

Toh, T. C., Ting, C., Ali, K. N., Aliagha, G. U., \& Munir, O. (2012). Critical cost factors of building construction projects 
in Malaysia. Procedia-Social and Behavioral Sciences, 57, 360367. https://doi.org/10.1016/j.sbspro.2012.09.1198

Torp, O., Belay, A. M., Thodesen, C., \& Klakegg, O. J. (2016). Cost development over-time at construction planning phase: Empirical evidence from Norwegian construction projects. Procedia Engineering, 145, 1177-1184. https://doi.org/10.1016/j.proeng.2016.04.152

Wa'el, A., Mohd. Razali, Azizah, S., \& Ernawati, M. K. (2007). The significant factors causing delay of building construction projects in Malaysia. Engineering, Construction and Architectural Management, 14(2), 192-206.

https://doi.org/10.1108/09699980710731308
Xu, H., Zhao, S., Mahmoudi, A., \& Feylizadeh, M. R., (2019). A rework reduction mechanism in complex projects using design structure matrix clustering methods. Transactions of Nanjing University of Aeronautics and Astronautics, 36(2), 264-279.

Zidane, Y. J., Johansen, A., Andersen, B., \& Hoseini, E. (2015). Time-thieves and bottlenecks in the Norwegian construction projects. Procedia Economics and Finance, 21, 486-493. https://doi.org/10.1016/S2212-5671(15)00203-8 